\title{
Differential response to stress in Ostrea lurida as measured by gene expression
}

\author{
J. Emerson Heare ${ }^{1}$ ， Samuel J. White ${ }^{1}$ ， Brent Vadopalas ${ }^{1}$ ， Steven B. Roberts ${ }^{\text {Corresp. }{ }^{1}}$ \\ ${ }^{1}$ School of Aquatic and Fishery Sciences, University of Washington, Seattle, Washington, United States \\ Corresponding Author: Steven B. Roberts \\ Email address: sr320@uw.edu
}

Olympia oysters are the only oyster native to the west coast of North America. The population within Puget Sound, WA has been decreasing significantly since the early 1900 's. Current restoration efforts are focused on supplementing local populations with hatchery bred oysters. A recent study by Heare et al. (2015) has shown differences in stress response in oysters from different locations in Puget Sound however, nothing is known about the underlying mechanisms associated with these observed differences. In this study, expression of genes associated with growth, immune function, and gene regulatory activity in oysters from Oyster Bay, Dabob Bay, and Fidalgo Bay were characterized following temperature and mechanical stress. We found that heat stress and mechanical stress significantly changed expression in molecular regulatory activity and immune response, respectively. We also found that oysters from Oyster Bay had the most dramatic response to stress at the gene expression level. These data provide important baseline information on the physiological response of Ostrea lurida to stress and provide clues to underlying performance differences in the three populations examined. 


\section{Abstract}

13 Olympia oysters are the only oyster native to the west coast of North America. The population within Puget Sound, WA has been decreasing significantly since the early 1900's. Current restoration efforts are focused on supplementing local populations with hatchery bred oysters. A recent study by Heare et al. (2015) has shown differences in stress response in oysters from different locations in Puget Sound however, nothing is known about the underlying mechanisms associated with these observed differences. In this study, expression of genes associated with growth, immune function, and gene regulatory activity in oysters from Oyster Bay, Dabob Bay, and Fidalgo Bay were characterized following temperature and mechanical stress. We found that heat stress and mechanical stress significantly changed expression in molecular regulatory activity and immune response, respectively. We also found that oysters from Oyster Bay had the most dramatic response to stress at the gene expression level. These data provide important baseline information on the physiological response of Ostrea lurida to stress and provide clues to underlying performance differences in the three populations examined. 


\section{Introduction}

Olympia oysters, Ostrea lurida, are the only native oyster species on the west coast of North America. The species inhabits bays and estuaries within Puget Sound, WA. Ostrea lurida is typically smaller than the introduced Pacific oyster, Crassostrea gigas, with adults attaining an average size between $40-60 \mathrm{~mm}$ (Hopkins, 1937; Baker, 1995). As protandric hermaphrodites, Olympia oysters usually spawn as both male and female within the first year (Coe, 1932; Hopkins, 1937; Baker, 1995). Unlike C. gigas, O. lurida does not release its eggs into the water column. Instead females collect planktonic sperm balls and larvae are brooded for approximately two weeks before being released into the water column. The adults are sessile and are typically moved via predator interactions or wave action. Colonizing lower intertidal habitats, $O$. lurida typically can be found in the inner portions of bays or estuaries where dynamic conditions can shape the phenotypes of local populations (Baker, 1995; White et al., 2009).

Loss of habitat due to invasive species, overharvest, and pollution have greatly reduced the native Olympia oyster population. Although restoration efforts are underway, basic research is needed to understand how this species interacts with its environment and responds to stress. Freshwater influx, tidal exchange, food availability, shifts in water temperature, and physical stresses from water flow and predation are examples of a myriad of stressors which affect long term survival of O. lurida populations (Hopkins, 1937; Baker, 1995).

Thermal stress has been widely studied in mollusks, especially bivalves. Ostrea lurida has a temperature tolerance range between $5^{\circ} \mathrm{C}-39^{\circ} \mathrm{C}$ (Hopkins, 1937; Brown et al., 2004). It is suspected that mass summer mortalities of $C$. gigas may be linked to the effects of heat stress during spawning events ( $\mathrm{Li}$ et al., 2007b). The California mussel, Mytilus californianus, has been found to divert resources to physiological defense during thermal stress events (Petes, Menge, and Harris, 2008; Fitzgerald-Dehoog, Browning and Allen, 2012). Expression of homeostasisrelated genes, such as HSP70, glutamine synthetase, and citrate synthase in $C$. gigas has been shown to fluctuate under prolonged heat stress at $25^{\circ} \mathrm{C}$ for 24 days (Meistertzheim et al. 2007). Temperature stress has been shown to induce a variety of up and down regulation of genes to maintain homeostasis (Tomanek, 2010). In oysters, there has been a significant amount of work examining the change in heat shock protein (HSP) family gene expression. Seasonal variation of HSPs and heat shock cognates (HSCs) levels have been characterized in response to ambient temperatures for C. gigas (Hamdoun, Cheney, and Cherr, 2003; Farcy et al., 2009). Additionally, induction of HSP70 and HSP69 in Ostrea edulis at temperatures greater than $38^{\circ} \mathrm{C}$ have been reported (Piano et al., 2005).

The response of bivalves to mechanical stress has also received considerable attention. One reason for this is that researchers have shown mechanical stress elicits a classical stress response, providing a simple method to allow for investigation of fundamental physiological stress responses. Additionally, most oyster restoration and aquaculture practices do involve handling and movement which would be a form of mechanical stress. Mechanical stress in oysters has been shown to increase catecholamines present in hemolymph (Qu et al., 2009; Lacoste et al., 2001c). Upon mechanical stress, researchers have found increases in adrenocorticotropic hormone $(\mathrm{ACTH})$, a hormone that induces production of noradrenaline and dopamine (Lacoste et al. 2001a; Lacoste et al., 2001b; Lacoste et al., 2001c). Mechanical stress has also been shown to activate inflammation factors that are also observed during bacterial challenges (Lacoste et al., 2001c; Lacoste et al., 2001d; Aladaileh, Nair, and Raftos, 2008; Roberts et al., 2011). Studies in Pearl oysters (Imbricata pinctada) have found significant decreases in phagocytosis and phenoloxidase activity due to mechanical stress (Kuchel, Raftos, and Nair, 2010;). 
72

73

74

75

76

77

78

79

80

81

82

83

84

85

86

87

88

89

90

91

92

93

94

95

96

97

98

99

100

101

102

103

104

105

106

107

108

109

110

111

112

113

114

115

Here we set out to examine the effects of temperature and mechanical stress on Ostrea lurida, by comparing differences in gene expression among three local populations (Heare et al., 2015). Each of the three populations comes from distinct bays within Puget Sound, WA: Fidalgo Bay, Dabob Bay, and Oyster Bay. Fidalgo Bay, the furthest northern population (48 $28^{\prime} 31.1^{\prime \prime} \mathrm{N}$ $\left.122^{\circ} 34^{\prime} 48.6^{\prime \prime} \mathrm{W}\right)$, is directly fed from the Salish Sea and the Strait of Juan de Fuca, and has the coldest average year-round temperatures of the three locations. Typically, this population does not experience strong fluctuations in temperatures due to the fact that it resides in the lower part of the intertidal area and is submerged for most of the time. Olympia oysters from Fidalgo Bay experience significant growth when placed in warmer habitats, but otherwise lack other observable phenotypes (Heare et al., 2015). Dabob Bay $\left(47^{\circ} 49^{\prime} 27.4^{\prime \prime N} 122^{\circ} 48^{\prime} 37.9^{\prime \prime} \mathrm{W}\right)$ is a large bay at the northern most portion of Hood Canal with the population of Olympia oysters residing near the innermost portions of the bay (e.g. Tarboo Creek). This area experiences extreme temperature fluctuations throughout the year and this population of O.lurida is often partially, or completely, exposed during low tide events. During tidal changes, temperatures can be as high as $29^{\circ} \mathrm{C}$ during summer or as low as $-3^{\circ} \mathrm{C}$ during winter (Heare et al., 2015). Oysters from Dabob Bay have been shown to experience high survival when faced with temperature challenges, possibly due to adaptive structure of the local population (Heare et al., 2015). Oyster Bay $\left(47^{\circ} 06^{\prime} 21.2^{\prime \prime} \mathrm{N} 123^{\circ} 04^{\prime} 32.8^{\prime \prime} \mathrm{W}\right)$ is the southernmost bay which sustains a healthy population of O. lurida. The conditions here are, on average, the warmest of the three locations throughout the year. The bay has extensive food resources and oysters appear to allocate more energy resources into reproductive activity compared to the other populations, based on our prior field studies (Heare et al. 2015).

For long-term restoration of $O$. lurida populations in Puget Sound, understanding the phenotypic plasticity of individual populations will help determine proper supplementation procedures for existing and historic habitats. To this end, and to attempt reveal relationship of gene expression response with stress exposure, we investigated differences between these populations in their responses to mechanical and temperature stresses, based on mRNA expression of select target genes as measured by quantitative PCR (qPCR). A suite of genes was selected based on their predicted functions related to gene regulation, immune response, and growth. Given the field performance of these populations, we hypothesized we would see differences in response that could be indicative of underlying genetic population differences. A specific hypothesis is that oysters from Dabob Bay will demonstrate a more pronounced response to stress via changes in gene expression.

\section{Materials and Methods}

\section{Experimental Design}

Adult, hatchery produced oysters from three wild source populations (Dabob Bay, Fidalgo Bay, and Oyster Bay grown for 19 months at Clam Bay, WA were used for this experiment. All oysters were held at $8^{\circ} \mathrm{C}$ for two weeks at the University of Washington prior to the experiment. Oysters from each population ( $\mathrm{n}=8$ per population) were subjected to acute temperature stress (submerged in $500 \mathrm{~mL} 38^{\circ} \mathrm{C}$ sea water for 1 hour), mechanical stress (120g x $5 \mathrm{~min}$; Sorvall T21, ST-H750 rotor) or served as controls (maintained at $8^{\circ} \mathrm{C}$ ). After the stress treatments, oysters were returned to $8^{\circ} \mathrm{C}$ seawater and sampled at 1 hour post stress $(n=72)$. Ctenidia tissue was resected from each individual and stored separately in 500 $\mu \mathrm{L}$ RNAzol RT (Molecular Research Center, Inc.), frozen on dry ice. All samples were stored at $-80^{\circ} \mathrm{C}$ for later analysis. 
117 RNA was isolated using RNAzol RT (Molecular Research Center, Inc.) according to the 118 manufacturer's protocol for total RNA isolation. Briefly, ctenidia tissue was homogenized in 119 RNAzol RT, volume was brought up to $1 \mathrm{~mL}$ with RNAzol RT, vortexed vigorously for 15 120 seconds, and incubated at room temperature (RT) for 10 minutes. $400 \mu \mathrm{L}$ of $0.1 \%$ DEPC-H2O was added to the homogenized ctenidia tissue, vortexed for 15 seconds, and incubated at RT for 15 minutes. The samples were centrifuged for 15 minutes, $16,000 \mathrm{~g}$, at RT. After centrifugation, $750 \mu \mathrm{L}$ of the supernatant was transferred to a clean tube, an equal volume of isopropanol added, vortexed for 10 seconds, and incubated at RT for 15 minutes. The samples were centrifuged at $12,000 \mathrm{~g}$ for 10 minutes at RT. The supernatant was discarded and the pellets were washed with $500 \mu \mathrm{L}$ of $75 \%$ ethanol (made with $0.1 \%$ DEPC-H2O) and centrifuged at 4,000g for 3 minutes at room temperature. This wash step was then repeated. Ethanol was removed and pellets were resuspended in $100 \mu \mathrm{L}$ of $0.1 \%$ DEPC-H2O. Samples were quantified using a NanoDrop1000 (ThermoFisher) and stored at -80C.

\section{DNase Treatment and Reverse Transcription}

131 Total RNA was treated with DNase to remove residual genomic DNA (gDNA) using the Turbo 132 DNA-free Kit (Ambion/Life Technologies). The manufacturer's rigorous protocol was followed. 133 Briefly, $1.5 \mu \mathrm{g}$ of total RNA was treated in $0.5 \mathrm{~mL}$ tubes in a reaction volume of $50 \mu \mathrm{L}$. The 134 samples were incubated with $1 \mu \mathrm{L}$ of DNase for 30 minutes at $37 \mathrm{C}$. An additional $1 \mu \mathrm{L}$ of DNase 135 was added to each sample and incubated at $37^{\circ} \mathrm{C}$ for an additional 30 minutes. The DNase was 136 inactivated with 0.2 volumes of the inactivation reagent according to the manufacturer's protocol. 137 Samples were quantified using a NanoDrop1000 (ThermoFisher). Treated RNA was verified to 138 be free of gDNA via qPCR using actin primers (see Primer Design section below) known to 139 amplify gDNA.

140 Reverse transcription was performed using M-MLV Reverse Transcriptase (Promega) with oligo dT primers (Promega), using 250ng of DNased RNA. The RNA was combined with primers $(0.25 \mathrm{ug})$ in a volume of $74.75 \mathrm{uL}$, incubated at $70^{\circ} \mathrm{C}$ for 5 minutes in a thermal cycler without a heated lid (PTC-200; MJ Research), and immediately placed on ice. A master mix of 5x Reverse Transcriptase Buffer (1x final concentration; Promega), $10 \mathrm{mM}$ each of dNTPs $(0.5 \mathrm{mM}$ final concentration of each dNTP; Promega), and M-MLV Reverse Transcriptase (50U/reaction) was made and $25.25 \mu \mathrm{L}$ of the mix was added to each sample (final reaction volume $100 \mu \mathrm{L}$ ). Samples were incubated at $42^{\circ} \mathrm{C}$ for $1 \mathrm{hr}$, followed by $95^{\circ} \mathrm{C}$ for 3 minutes in a thermal cycler without a heated lid (PTC-200; MJ Research), and then stored at $-20^{\circ} \mathrm{C}$.

\section{Quantitative PCR}

\section{Primer Design}

151 Primers for qPCR analysis were developed from an O. lurida transcriptome (version 3) which can

152 find in the repository associated with this manuscript (Roberts 2017). This transcriptome was

153 annotated using SwissProt and Gene Ontology Databases. Specifically, gene function annotations

154 were based on the protein in the UniProt/SwissProt database that had highest homology with the

155 Olympia oyster sequence (i.e. top Blastp hit).. Gene targets were selected based on annotations

156 related to gene regulation, immune response, and growth (Table 1). Corresponding contigs were

157 then selected from the transcriptome using the seqinR package (Charif and Lobry, 2007). NCBI

158 Primer Blast was used to develop primers for qPCR using the following parameters: amplicon 
159 size $100-400 \mathrm{bp}, \mathrm{GC}$ content $55-60 \%$, melt temperatures $\sim 60{ }^{\circ} \mathrm{C}$ and within $0.5{ }^{\circ} \mathrm{C}$ of each other, 160 self and 3' complementarity was limited to 4.00 or less with smallest values being selected, 161 primer sequence $19-21 \mathrm{bp}$ in length.

162 Primer binding sites were assessed for the presence of single nucleotide polymorphisms (SNPs) 163 via Sanger sequencing. The majority of primer binding sites did not contain any SNPs. Those that 164 did, had only a single SNP and did not appear to impact qPCR data, as there were no noticeable 165 difference in qPCR efficiencies in individuals having a SNP within a primer binding site for a 166 given target.

167 List of primers can be viewed in Table 2.

Uniprot Annotation

Function

Gene Abbr

BLASTX evalue comp7220_c0_seq2

Gene Regulation

Q6DC04

CARM1_DANRE

Histone-arginine methyltransferase

Transfers methyl groups to Histone 3 for chromatin remodeling

CARM1

0

comp23747_c0_seq1

Immune Response

Q9DD78

TLR21_CHICK

Toll-like receptor 2 type 1

Assists with recognition of foreign pathogens and endogenous materials for consumptions by phagocytes in early stages of inflammation

TLR

8.00E-29

comp25000 c0 seq1

Gene Regulation

P08991

H2AV_STRPU

Histone H2A.V

One of 5 main Histone Proteins involved in the structure of chromatin and the open reading frame of DNA 
198 H2AV

$199 \quad 5.00 \mathrm{E}-64$

200 comp24065_c0_seq1

201 Immune Response

202 O75594

203 PGRP1_HUMAN

204 Peptidoglycan recognition protein 1

205 Assists with recognition of bacteria in an immune response

206 PGRP

$207 \quad 2.00 \mathrm{E}-42$

208 comp44273_c0_seq2

Immune Response

Q8MWP4

Q8MWP4 OSTED

Heat Shock Protein $70 \mathrm{kD}$

Molecular chaperone and protein preservation in heat response

HSP70

0

comp7183_c0_seq1

Growth

P12643

BMP2 HUMAN

Bone morphogenetic protein 2

Directs calcification in shell creation

BMP2

$2.00 \mathrm{E}-93$

comp10127_c0_seq1

Growth

P62994

GRB2_RAT

Growth factor receptor-bound protein 2

Assists in signal transduction/cell communication

GRB2

$1.00 \mathrm{E}-83$

comp6939 c0 seq1

Immune Response

P32240

PE2R4 MOUSE

Prostaglandin E2 receptor EP4 subtype

Receptor for Prostaglandin E2 which suppresses inflammation due to injury

PGEEP4

$1.00 \mathrm{E}-50$

comp25313_c0_seq1

Immune Response

Q60803

TRAF3_MOUSE

Tumor Necrosis Factor receptor-associated factor 3

Related to immune response specifically cell death initiation

TRAF3

3.00E-145

comp30443_c0_seq2

Q8TA69

Q8TA69 CRAGI

Actin

Cytoskeletal formation. 


\begin{tabular}{|c|c|c|c|c|c|c|c|}
\hline $\begin{array}{l}\text { Transcriptome Contig } \\
\text { Name }\end{array}$ & $\begin{array}{l}\text { Biological I } \\
\text { Category }\end{array}$ & $\begin{array}{l}\text { Uniprot } \\
\text { Accession }\end{array}$ & $\begin{array}{l}\text { Uniprot Entry } \\
\text { Name }\end{array}$ & $\begin{array}{l}\text { Uniprot } \\
\text { Annotation }\end{array}$ & Function & Gene Abbr & $\begin{array}{l}\text { BLASTX } \\
\text { evalue }\end{array}$ \\
\hline comp7220_c0_seq2 & $\begin{array}{l}\text { Immune } \\
\text { Response, } \\
\text { Gene } \\
\text { Regulation }\end{array}$ & Q6DC04 & CARM1_DANRE & $\begin{array}{l}\text { Histone-arginine } \\
\text { methyltransferase }\end{array}$ & $\begin{array}{l}\text { Transfers methyl } \\
\text { groups to Histone } 3 \\
\text { e for chromatin } \\
\text { remodeling }\end{array}$ & CARM1 & 0 \\
\hline comp23747_c0_seq1 & $\begin{array}{l}\text { Immune } \\
\text { Response }\end{array}$ & Q9DD78 & TLR21_CHICK & $\begin{array}{l}\text { Toll-like receptor } \\
2 \text { type } 1\end{array}$ & $\begin{array}{l}\text { Assists with } \\
\text { recognition of } \\
\text { foreign pathogens } \\
\text { and endogenous } \\
\text { materials for } \\
\text { consumptions by } \\
\text { phagocytes in early } \\
\text { stages of } \\
\text { inflammation }\end{array}$ & TLR & $8.00 \mathrm{E}-29$ \\
\hline comp25000_c0_seq1 & $\begin{array}{l}\text { Immune } \\
\text { Response, } \\
\text { Gene } \\
\text { Regulation }\end{array}$ & P08991 & H2AV_STRPU & Histone H2A.V & $\begin{array}{l}\text { One of } 5 \text { main } \\
\text { Histone Proteins } \\
\text { involved in the } \\
\text { structure of } \\
\text { chromatin and the } \\
\text { open reading frame } \\
\text { of DNA }\end{array}$ & $\mathrm{H} 2 \mathrm{AV}$ & $5.00 \mathrm{E}-64$ \\
\hline comp24065_c0_seq1 & $\begin{array}{l}\text { Immune } \\
\text { Response }\end{array}$ & O75594 & PGRP1_HUMAN & $\begin{array}{l}\text { Peptidoglycan } \\
\text { recognition } \\
\text { protein } 1\end{array}$ & $\begin{array}{l}\text { Assists with } \\
\text { recognition of } \\
\text { bacteria in an } \\
\text { immune response }\end{array}$ & PGRP & $2.00 \mathrm{E}-42$ \\
\hline comp44273_c0_seq2 & $\begin{array}{l}\text { Immune } \\
\text { Response }\end{array}$ & Q8MWP4 & Q8MWP4_OSTED & $\begin{array}{l}\text { Heat Shock } \\
\text { Protein } 70 \mathrm{kDa}\end{array}$ & $\begin{array}{l}\text { Molecular } \\
\text { chaperone and } \\
\text { protein preservation } \\
\text { in heat response }\end{array}$ & HSP70 & 0 \\
\hline comp7183_c0_seq1 & Growth & P12643 & BMP2_HUMAN & $\begin{array}{l}\text { Bone } \\
\text { morphogenetic } \\
\text { protein } 2\end{array}$ & $\begin{array}{l}\text { Directs calcification } \\
\text { in shell creation }\end{array}$ & BMP2 & $2.00 \mathrm{E}-93$ \\
\hline comp10127_c0_seq1 & $\begin{array}{l}\text { Gene } \\
\text { Regulation }\end{array}$ & P62994 & GRB2_RAT & $\begin{array}{l}\text { Growth factor } \\
\text { receptor-bound } \\
\text { protein } 2\end{array}$ & $\begin{array}{l}\text { Assists in signal } \\
\text { transduction/cell } \\
\text { communication }\end{array}$ & GRB2 & $1.00 \mathrm{E}-83$ \\
\hline comp6939_c0_seq1 & $\begin{array}{l}\text { Immune } \\
\text { Response }\end{array}$ & P32240 & PE2R4_MOUSE & $\begin{array}{l}\text { Prostaglandin E2 } \\
\text { receptor EP4 } \\
\text { subtype }\end{array}$ & $\begin{array}{l}\text { Receptor for } \\
\text { Prostaglandin E2 } \\
\text { which suppresses } \\
\text { inflammation due to } \\
\text { injury }\end{array}$ & PGEEP4 & $1.00 \mathrm{E}-50$ \\
\hline comp25313_c0_seq1 & $\begin{array}{l}\text { Immune } \\
\text { Response }\end{array}$ & Q60803 & TRAF3_MOUSE & $\begin{array}{l}\text { Tumor Necrosis } \\
\text { Factor receptor- } \\
\text { associated factor } \\
3\end{array}$ & $\begin{array}{l}\text { Related to immune } \\
\text { response specifically } \\
\text { cell death initiation }\end{array}$ & TRAF3 & $\begin{array}{l}3.00 \mathrm{E}- \\
145\end{array}$ \\
\hline comp30443_c0_seq2 & Growth & Q8TA69 & Q8TA69_CRAGI & Actin & $\begin{array}{l}\text { Cytoskeletal } \\
\text { formation. } \\
\text { Used as a } \\
\text { normalizing gene for } \\
\text { qPCR analysis. }\end{array}$ & Actin & 0 \\
\hline
\end{tabular}

256 Table 1. Table of genes of interest. The table lists the source transcriptome contigs (annotated by BLASTx against the Uniprot database), as well as the biological categorization, the Uniprot Accession, Uniprot Entry Name, Uniprot Annotation, a brief description of the proteins'

259 functions, and the BLASTx e-values.

260 Gene Abbreviation

261 FWD

262 REV

263 CARM1

264 TGGTTATCAACAGCCCCGAC

265 GTTGTTGACCCCAGGAGGAG

266 TLR 
267 ACAAAGATTCCACCCGGCAA

268 ACACCAACGACAGGAAGTGG

$269 \mathrm{H} 2 \mathrm{AV}$

270 TGCTTTCTGTGTGCCCTTCT

271 TATCACACCCCGTCACTTGC

272 PGRP

273 GAGACTTCACCTCGCACCAA

274 AACTGGTTTGCCCGACATCA

275 HSP70

276 TTGTCGCCATTTTCCTCGCT

277 GTTCCGATTTGTTCCGTGCC

278 BMP2

279 TGAAGGAACGACCAAAGCCA

280 TCCGGTTGAAGAACCTCGTG

281 GRB2

282 AACTTTGTCCACCCAGACGG

283 CCAGTTGCAGTCCACTTCCT

284 PGEEP4

285 ACAGCGACGGACGATTTTCT

286 ATGGCAGACGTTACCCAACA

287 TRAF3

288 AGCAGGGCATCAAACTCTCC

289 ACAAGTCGCACTGGCTACAA

290 Actin

291 GACCAGCCAAATCCAGACGA

292 CGGTCGTACCACTGGTATCG

\begin{tabular}{|l|l|l|}
\hline Gene Abbreviation & \multicolumn{1}{|c|}{ FWD } & \multicolumn{1}{c|}{ REV } \\
\hline CARM1 & TGGTTATCAACAGCCCCGAC & GTTGTTGACCCCAGGAGGAG \\
\hline TLR & ACAAAGATTCCACCCGGCAA & ACACCAACGACAGGAAGTGG \\
\hline H2AV & TGCTTTCTGTGTGCCCTTCT & TATCACACCCCGTCACTTGC \\
\hline PGRP & GAGACTTCACCTCGCACCAA & AACTGGTTTGCCCGACATCA \\
\hline HSP70 & TTGTCGCCATTTTCCTCGCT & GTTCCGATTTGTTCCGTGCC \\
\hline BMP2 & TGAAGGAACGACCAAAGCCA & TCCGGTTGAAGAACCTCGTG \\
\hline GRB2 & AACTTTGTCCACCCAGACGG & CCAGTTGCAGTCCACTTCCT \\
\hline PGEEP4 & ACAGCGACGGACGATTTTCT & ATGGCAGACGTTACCCAACA \\
\hline TRAF3 & AGCAGGGCATCAAACTCTCC & ACAAGTCGCACTGGCTACAA \\
\hline Actin & GACCAGCCAAATCCAGACGA & CGGTCGTACCACTGGTATCG \\
\hline
\end{tabular}


293 Table 2. Table of qPCR Primers for genes of interest. Includes the Uniprot Entry Name, the Gene 294 Abbreviation used throughout this manuscript, and the forward (FWD) and reverse (REV) primer 295 sequences. Full sequences utilized for primer creation are available. (Heare and Roberts 2015).

296

297

298

299

300

301

302

303

304

305

306

307

308

309

310

311

312

313

314

315

316

317

318

319

320

321

322

\section{Quantitative PCR}

Quantitative PCR reactions were carried out using Ssofast Evagreen Supermix (BioRad, USA). Forward and reverse primers (Integrated DNA Technologies) were used at a final concentration of $0.25 \mathrm{uM}$ each. Sample cDNA was diluted (1:9) with molecular-grade water. Nine microliters of diluted cDNA was used as template. Reaction volumes were $20 \mu \mathrm{L}$ and were run in low-profile, non-skirted, white qPCR plates (USA Scientific) with optically clear lids (USA Scientific) in a BioRad CFX Real Time Thermocycler (BioRad, USA) and DNA Engine Opticon 2 System (BioRad, USA). Cycling conditions were: one cycle of $95^{\circ} \mathrm{C}$ for $10 \mathrm{~min}$; 40 cycles of $95^{\circ} \mathrm{C}$ for 30 $\mathrm{sec}, 60^{\circ} \mathrm{C}$ for $1 \mathrm{~min}, 72^{\circ} \mathrm{C}$ for $30 \mathrm{sec}$. Two qPCR replicates were run for each sample, for each primer set.

\section{Statistical Analysis}

To calculate relative expression levels for each gene, cycle quantity $(\mathrm{Cq})$ or cycle threshold $(\mathrm{Ct})$ values were calculated using BioRad CFX Manager 3.1 (version 3.1.1517.0823, Windows 8.1) and Opticon Manager 3 (Windows 8.1), respectively. This was accomplished by subtracting global minimum fluorescence from samples and determining the point in the cycle which amplification reached exponential amplification phase. Default settings were accepted for each program to ensure reproducibility. The BioRad CFX Manager used default settings of single threshold for $\mathrm{Cq}$ determination and baseline subtracted curved fit for each run. The Opticon Manager used default settings of subtract baseline via global minimum, which estimated the threshold as being between 0.019 and 0.028 . Gene expression values were determined as normalized mRNA levels using the following equation $(\Delta \mathrm{Ct}): 2^{-\Delta \mathrm{Ct}}$; where $\Delta \mathrm{Ct}$ is: (target $\mathrm{Ct}-$ actin $\mathrm{Ct}$ ) (Schmittgen and Livak, 2008). Actin expression levels were determined to be consistent across all samples and served as an internal amplification control to use for expression normalization. Data from $\Delta \mathrm{Ct}$ did not exhibit normal distributions, so were log transformed $(\log \Delta \mathrm{Ct})$, to establish normal data distributions for statistical analysis. Two-way analysis of variance (ANOVA) followed by Tukey's Honestly Significant Difference post hoc test (base, $\mathrm{R}$ Core Team, 2014) were performed on $\log \Delta \mathrm{Ct}$ for each target $(\mathrm{p}<0.05)$.

\section{Results}

\section{Gene Expression Analysis}

Without considering separate populations, acute heat shock resulted in statistically significant increases in expression of coactivator-associated arginine methyltransferase 1 (CARM1) ( $\mathrm{n}=24$ oysters per treatment, ANOVA, $d f=2$, Tukey's HSD $p=0.00007$ ) (Figure 1) and Histone 2AV (H2AV) ( $n=24$ oysters per treatment, ANOVA, $d f=2$, Tukey's HSD $\mathrm{p}=0.001)$ (Figure 2). A statistically significant increase in expression of tumor necrosis factor receptor-associated factor 3 (TRAF3) (n=24 oysters per treatment, ANOVA, df=2, Tukey’s HSD p=0.008) (Figure 3) occurred upon exposure to mechanical stress. 
332 There was a clear difference in response to mechanical stress in oysters from Oyster Bay as

333 compared to oysters from Dabob and Fidalgo Bays. Specifically, upon heat shock, H2AV

334 expression in oysters from Oyster Bay increased $(n=8$ oysters per population, ANOVA, $d f=4$,

335 Tukey's HSD = 0.05) (Figure 2) when compared to the control. When exposed to mechanical

336 stress, bone morphogenic protein 2 (BMP2) ( $\mathrm{n}=8$ oysters per population, ANOVA, df=4, Tukey's

337 HSD $\mathrm{p}=0.03$ ) (Figure 4) and growth-factor receptor bound protein 2 (GRB2) (n=8 oysters per

338 population, ANOVA, $\mathrm{df}=4$, Tukey's HSD $\mathrm{p}=0.03$ )(Figure 5) expression was decreased in the

339 Oyster Bay population, whereas there was no significant differences in responses in the other

340 populations. Additionally, significant interactions were identified between population and

341 treatment in both BMP2 and GRB2 $(\mathrm{p}<0.05)$.

342 There was no statistical difference in expression in Peptidoglycan recognition protein 1 (PGRP),

343 toll-like receptor 2 type 1 (TLR), and prostaglandin E2 receptor EP4 subtype (PGEEP4) (Figures

$3446,7, \& 8$, respectively) within any comparison. Heat shock protein 70 gene expression was

345 significantly different between temperature and mechanical stress $(n=24$ oysters per treatment,

346 ANOVA, df=4, Tukey's HSD p=0.006) (Figure 9).

\section{Discussion}

\section{Response to Temperature Stress}

349 The response of Ostrea lurida to acute heat stress appears to include an alteration in gene

350 regulatory activity and the innate immune response, as indicated by significant increases of

351 H2AV (Figure 2) and CARM1 (Figure 2) gene expression one hour post-temperature stress.

352 Histone $2 \mathrm{AV}, \mathrm{H} 2 \mathrm{AV}$, is a variant of the histone $\mathrm{H} 2 \mathrm{~A}$ protein. This variant has been shown to act as 353 a transcription promoter agent as well as assist with heterochromatin formation. Truebano et al. 354 (2010) characterized changes in transcription in Antarctic clams, L. elliptica, and found that an $355 \mathrm{H} 2 \mathrm{~A}$ variant was significantly upregulated under heat stress conditions $\left(3{ }^{\circ} \mathrm{C}\right.$ for 12 hours). In 356 addition to involvement in the heat stress response, histone $\mathrm{H} 2 \mathrm{~A}$ has been shown to exhibit 357 antimicrobial properties in three invertebrates: two marine invertebrates (Pacific white shrimp 358 and scallops; Patat et al., 2004, Li et al., 2007a), as well as in a freshwater shrimp (Arockiaraj et 359 al., 2013). In D. melanogaster, H2Av is phosphorylated in response to DNA damage (Madigan et

360 al., 2002) to inhibit apoptosis, suggesting an additional role in in cellular survival.

361 Coactivator-associated arginine methyltransferase 1, CARM1, is involved transcriptional

362 activation via methylation of histones (Chen et al., 1999, Lee et al., 2005). This in turn affects the

363 ability of transcription factors to bind and transcription to proceed. It is possible that increases in

364 CARM1 expression could indicate that overall gene regulatory activity is increased in response to

365 temperature stress. Our results are similar to those of Wang et al. (2011) where researchers

366 described an increase in expression of Histone-arginine methyltransferase in the sea cucumber,

367 Apostichus japonicus, after experiencing $25^{\circ} \mathrm{C}$ temperatures for 7 days. The authors suggested

368 that this was due to an induced dormancy and lower metabolic rate to provide resources for stress

369 resilience. CARM1 is also a component of the cellular immune response, as it has been identified

370 as a regulator of NF-kB (Covic et al., 2005). Thus another explanation is that acute heat could

371 possible impact the immune response, likely in a negative manner. Future work, that would be 
372 relevant to restoration activities, should increase the number of stressors examined in oyster to

373 include pathogens.

374 Increases in HSPs are often observed in response to stress, but this study only found a significant 375 difference of mRNA expression of HSP70 in the Oyster Bay population between mechanical and 376 heat stresses (Figure 9). Brown et al. (2004) found the maximum HSP expression in O. lurida 377 occurred $24-48$ hours post exposure to $39^{\circ} \mathrm{C}$. The absence of a strong response of HSP70, relative 378 to the control group, could be related to temporal changes in expression or an isoform-specific 379 response, as there are many genes in this gene family, particularly in oysters (Clegg et al., 1998; 380 Piano et al., 2005). Mediterranean mussels, Mytilus galloprovincialis, have shown different 381 isoforms of heat shock proteins and cognates that have differential expression patterns caused by 382 heat, mercury exposure, and chromium exposures stressors suggesting that the isoforms have 383 slightly different functions (Franzellitti and Fabbri, 2005). Additionally, there are members of the 384 HSP70 gene family that are constitutively expressed and do not exhibit increases in mRNA in 385 response to heat stress (Sorger \& Pelham, 1987; Somji et al., 1999). Without a sequenced genome 386 for Ostrea lurida, combined with utilizing an incomplete transcriptome, it is difficult to ascertain 387 how many isoforms might exist, as well as the number of alternatively spliced products. Upon 388 addition of new genomic resources the entire family of molecular chaperones could be examined 389 and compared across populations.

\section{Response to Mechanical Stress}

Mechanical stress increased expression of inflammation-related target genes. In all populations, there was a significant increase in immune system-related responses seen via the expression of tumor necrosis factor receptor-associated factor 3, TRAF3 (Figure 3), which is involved in internal tissue damage recognition and apoptosis. The main function of TRAF3 is to assist in cell death initiation caused by stress conditions within tissues (Arch, Gedrich, and Thompson, 1998). Upregulation in relation to mechanical stress could be akin to inflammation occurring due to edema from the mechanical stress and used to remove damaged cells as suggested by Roberts et al. (2012) when $C$. virginica were exposed to mechanical stress. Significant differences in expression of other immune system targets such as PGRP, TLR, and PGEEP4 were not detected(Figures $6,7, \& 8$, respectively), but other studies have found that the time scale for expression may vary (Meistertzheim et al.,2007; Farcy et al., 2009).

\section{Population differences}

403 We suspected that the Dabob Bay population would have demonstrated a more pronounced 404 response to stress as this population is subjected to greater environmental fluctuations with 405 respect to salinity and temperature (Heare et al 2015).Contrary to our hypothesis, oysters from

406 Oyster Bay were the only population that exhibited a difference in gene expression in response to 407 mechanical or heat stress. Oysters from Oyster Bay parents showed an increase in H2AV 408 expression during heat stress as compared to control (Figure 2), a decrease in BMP2 and GRB2 409 upon mechanical stress (Figures 4 \& 5, respectively), and differences in HSP70 expression 410 between heat and mechanical stresses (Figure 9). Given the putative function of H2AV in 
411 transcriptional regulation (Table 1), the increase in expression could be indicative of the role of

412 this protein in controlling the molecular response to stress . Bone morphogenic protein 2, BMP2,

413 and growth-factor receptor bound protein 2, GRB2, were significantly decreased in expression

414 which could be indicative of growth inhibition. Both genes are related to growth and

415 development of tissues, with BMP2 being a pre-cursor to osteoblastic cells that produce shell

416 (Pereira Mouries et al., 2002) and GRB2 is used for signal transduction between cells during

417 growth phases (Oda et al., 2005). By down-regulating these targets, this may be an effort to

418 reduce energetically costly processes in favor of processes that promote survival during stress

419 events. Organisms faced with stress are often required to reallocate energy resources to

420 homeostasis-related functions in an effort to improve long-term survival of the species (Sokolova

421 et al., 2012). This change in expression coupled with the up-regulation of H2AV (Figure 2) is in

422 accord with the idea of shifting priorities for stress resilience.

423 Interactions were identified between population and treatment for both BMP2 and GRB2.

424 Differences between gene expression in control and mechanical stress in the Oyster Bay

425 population are driving this interaction for both genes. Although statistical interactions of this

426 nature are difficult to interpret, it could be related to fact the Oyster Bay population is from a

427 relatively "low-stress" environment (i.e. abundant food and less-pronounced temperature

428 fluctuations).

The gene expression pattern differences observed here with oysters from Oyster Bay coupled with corresponding field-based observation that this population has the greatest reproductive activity (Heare et al., 2015), could indicate this population has a greater ability to effectively respond to stress. Another way to consider this is that the Oyster Bay population has a relatively higher degree of phenotypic plasticity, or more specifically, an elevated rate of phenotypic change (Angilletta et al., 2003). The gene expression data indicates a clear population-level stress response, and lack of differential response in other populations that suggests shifts in energy balance. Some possible explanations for this relatively rapid response include a more sensitive cell-signaling system (ie cytokines) or a more robust transcription initiation process. Yao and Somero (2012) observed higher heat stress tolerance in M. galloprovincialis than M. californius likely due to their ability to maintain cell signaling through the production of phosphor-p38MAPK kinases, which may be how the Oyster Bay population is able to quickly respond to stress. This ability to quickly respond to stress may be due to increased fitness in Oyster Bay, however more research is needed to identify the link between gene expression and performance. Based on earlier field work, this could be directly linked to increased larval production, and processes allocating limited resources into reproduction (Heare et al., 2015). This trait could certainly be perceived as advantageous for restoration purposes. Caution should be used in using non-local stocks when structure exists, as it is possible to have supplemented oysters out-compete the native population or to create hybrids that are ultimately less fit than the native counter parts (Camara and Vadopalas, 2009). Both such phenomena decrease overall genetic diversity leaving the remaining population to be less robust for future challenges and possibly leading to local 451 extirpation. 
452 Another interpretation of gene expression patterns in the Oyster Bay population is that the 453 differences observed upon stress exposure are not indicative of an effective response that has 454 been selected for, but rather indicative of plasticity. In other words, the change in gene expression 455 upon stress is representative of a phenotype that is tolerable to a wide range of pressure. At one 456 level the ability to achieve a number of phenotypes with a given genotype could be advantageous, 457 458 particularly in a rapidly the changing environment. There is a paradox in the fact that too much plasticity negates the ability of natural selection to function. Populations with high phenotypic plasticity become deprived of negative selection and thus are often able to survive in rapidly changing environments as long as the changes are consistent and somewhat predictable. However, with this increased adaptive ability, genetic diversity and adaptation become limited within a population that may be unable to properly respond to novel challenges in the future (Crispo, 2008). Alternatively, the Baldwin effect may enhance longterm genetic diversity by allowing species to colonize novel habitats and, with phenotypic plasticity, and eventually genetically diverge from the source population through induced genetic adaptations (Crispo, 2007). For longterm restoration of $O$. lurida populations in Puget Sound, understanding the genetic differences and phenotypic plasticity of individual populations will help determine proper supplementation procedures for existing and historic habitats.

\section{Acknowledgements}

470

The authors would like to thank an anonymous reviewer and Marta Gomez-Chiarri for their

471 helpful insight and feedback upon initial submission of this manuscript for publication. We would

472 also like to thank Puget Sound Restoration Fund for providing the oysters used in these

473 experiments.

\section{Citations}

475 Aladaileh, S., Nair, S., \& D. Raftos. 2008. Effects of noradrenaline on immunological activity in 476 Sydney rock oysters. Dev. \& Comp. Immunology 32:627-636.

477 Angilletta Jr, M., Wilson, R., Navas, C., \& R. James R. 2003. Tradeoffs and the evolution of 478 thermal reaction norms. Trends in Eco. \& Evo. 18:234-240.

479 Arch, R., Gedrich, R., \&C. Thompson. 1998. Tumor necrosis factor receptor-associated factors 480 (TRAFs) - a family of adapter proteins that regulates life and death. Genes \& Dev. 12:28214812830.

482 Bailey, C.H., Bartsch, D., \& Kandel, E.R. 1996. Toward a molecular definition of long-term 483 memory storage. Proceedings of the National Academy of Sciences of the United States of 484 America 93:13445-13552.

485 Baker, P. 1995. Review of Ecology and Fishery of the Olympia Oyster, Ostrea lurida, with 486 Annotated Bibliography. J. of Shellfish Res. 14:503-518.

487 Biel, M., Wascholowski, V., \& A. Giannis. 2005. Epigenetics-An Epicenter of Gene Regulation: 488 Histones and Histone-Modifying Enzymes. Ang. Chem. Intl. Ed. 44:3186-3216.

489 Brown, H. M., A. Briden, T. Stokell, F. J. Griffin, \& G. N. Cherr. 2004. Thermotolerance and 490 Hsp70 profiles in adult and embryonic California native oysters, Ostrea conchaphila (Carpenter, 491 1857). J. of Shellfish Res. 23:135-141. 
492 Camara, M. \& B. Vadopalas. 2009. Genetic Aspects of Restoring Olympia Oysters and Other

493 Native Bivalves: Balancing the Need for Action, Good Intentions, and the Risks of Making

494 Things Worse. J. of Shellfish Res. 28:121-145.

495 Chen, D., Ma, H., Hong, H., Koh, S.S., Huang, S., Schurter, B.T., Aswad, D.W., Stallcup, M.R.

496 1999. Regulation of Transcription by a Protein Methyltransferase. Science 284:2174-2177.

497 Clegg, J., Uhlinger, K., Jackson, S., Cherr, G., Rifkin, E., \& C. Friedman. 1998. Induced

498 thermotolerance and the heat shock protein-70 family in the Pacific oyster Crassostrea gigas.

499 Mol. Mar. Bio and Biotech. 7:21-30

500 Crispo, E. 2008. Modifying effects of phenotypic plasticity on interactions among natural

501 selection, adaptation and gene flow. J. of Evo. Bio. 21:1460-1469.

502 Crispo, E. 2007. The Baldwin Effect and Genetic Assimilation: Revisiting Two Mechanisms of

503 Evolutionary Change Mediated by Phenotypic Plasticity. Evolution 61:2469-2479.

504 Davis, H. 1955. Mortality of Olympia Oysters at Low Temperatures. Bio. Bulletin 109:404-406.

505 Farcy, E., Voiseux, C., Lebel, J-M., \& B. Fievet. 2009. Transcriptional expression levels of cell

506 stress marker genes in the Pacific oyster Crassostrea gigas exposed to acute thermal stress. Cell

507 Str. \& Chap. 14:371-380.

508 Fitzgerald-Dehoog, L., Browning, J., \& BJ. Allen. 2012. Food and Heat Stress in the California

509 Mussel: Evidence for an Energetic Trade-off Between Survival and Growth. Bio. Bulletin

$510 \quad 223: 205-216$.

511 Franzellitti S. \& E. Fabbri. 2005. Differential HSP70 gene expression in the Mediterranean

512 mussel exposed to various stressors. Biochem. \& Biophys. Res. Comm. 336:1157-1163.

513 Hamdoun, A., Cheney, D., \& G. Cherr. 2003. Phenotypic Plasticity of HSP70 and HSP70 Gene

514 Expression in the Pacific Oyster (Crassostrea gigas): Implications for Thermal Limits and

515 Induction of Thermal Tolerance. Bio. Bulletin 205:160-169.

516 Heare, J., Blake, B., Davis, J., Vadopalas, B., \& S.B. Roberts. 2015. Evidence of Ostrea lurida

517 (Carpenter 1864) population structure in Puget Sound, WA. PeerJ preprint.

518 https://peerj.com/preprints/704/

519 Heare, J., \& S.B. Roberts. . https://github.com/jheare/OluridaGeneExpression/tree/v1.0

520 Hopkins, A. 1936. Ecological Observations on Spawning and Early Larval Development in the 521 Olympia Oyster (Ostrea lurida). Ecology 17:551-566.

522 Kuchel, R., Raftos, D., \& S. Nair. 2010. Immunosuppressive effects of environmental stressors 523 on immunological function in Pinctada imbricata. Fish \& Shellfish Immunology 29:930-936.

524 Lacoste, A., Malham, S., Cueff, A., Jalabert, F., Gelebart, F., \& S. Poulet. 2001a. Evidence for a 525 form of adrenergic response to stress in the mollusc Crassostrea gigas. J. of Exp. Bio. 204:12475261255.

527 Lacoste, A., Malham, S., Cueff, A., \& S. Poulet SA. 2001b. Noradrenaline modulates hemocyte 528 reactive oxygen species production via $\beta$-adrenergic receptors in the oyster Crassostrea gigas.

529 Dev. \& Comp. Immunology 25:285-289. 
530 Lacoste, A., Malham, S., Cueff, A.,\& S. Poulet. 2001c. Stress-Induced Catecholamine Changes in

531 the Hemolymph of the Oyster Crassostrea gigas. Gen. and Comp. Endo. 122:181-188.

532 Lacoste, A., Jalabert, F., Malham, S., Cueff, A., \& S. Poulet. 2001d. Stress and Stress-Induced

533 Neuroendocrine Changes Increase the Susceptibility of Juvenile Oysters (Crassostrea gigas) to

534 Vibrio splendidus. App. and Env. Micro. 67:2304-2309.

535 Lang, R., Bayne, C., Camara, M., Cunningham, C., Jenny, M., \& C. Langdon. 2009.

536 Transcriptome Profiling of Selectively Bred Pacific Oyster Crassostrea gigas Families that Differ

537 in Tolerance of Heat Shock. Mar. Biotech. 11:650-668.

538 Lathlean, J., \& T. Minchinton. 2012. Manipulating thermal stress on rocky shores to predict 539 patterns of recruitment of marine invertebrates under a changing climate. Fac. of Sci. - Papers

540 (Archive):121-136.

541 Lee, D.Y., Teyssier, C., Strahl, B.D., \& Stallcup, M.R. 2005. Role of Protein Methylation in 542 Regulation of Transcription. Endocrine Reviews 26:147-170.

543 Li, C., Song, L., Zhao, J., Zhu, L., Zou, H., Zhang, H., Wang, H., \& Cai, Z. 2007. Preliminary

544 study on a potential antibacterial peptide derived from histone H2A in hemocytes of scallop

545 Chlamys farreri. Fish \& Shellfish Immunology 22:663-672.

546 Li, Y., Qin, J., Abbott, C., Li, X., \& K. Benkendorff. 2007. Synergistic impacts of heat shock and 547 spawning on the physiology and immune health of Crassostrea gigas: an explanation for summer 548 mortality in Pacific oysters. AJP: Reg., Intgr. \& Comp. Phys. 293:R2353-R2362.

549 Madigan, J. P., Chotkowski, H.L., \& Glaser, R.L. 2002. DNA double-strand break-induced 550 phosphorylation of Drosophila histone variant H2Av helps prevent radiation-induced apoptosis.

551 Nucleic Acids Research 30:3698-3705.

552 Meistertzheim, A-L., Tanguy, A., Moraga, D.,\& M-T. Thébault. 2007. Identification of

553 differentially expressed genes of the Pacific oyster Crassostrea gigas exposed to prolonged

554 thermal stress. FEBS Journal 274:6392-6402.

555 Park, H., Ahn, I-Y., \& H. Lee. 2007. Expression of heat shock protein 70 in the thermally stressed 556 Antarctic clam Laternula elliptica. Cell Str. \& Chap. 12:275-282.

557 Patat, S.A., Carnegie, R.B., Kingsbury, C., Gross, P.S., Chapman, R., Schey, K.L. 2004.

558 Antimicrobial activity of histones from hemocytes of the Pacific white shrimp. European Journal 559 of Biochemistry 271:4825-4833.

560 Pereira Mouriès, L., Almeida, M-J., Milet, C., Berland, S., \& E. Lopez. 2002. Bioactivity of nacre 561 water-soluble organic matrix from the bivalve mollusk Pinctada maxima in three mammalian cell 562 types: fibroblasts, bone marrow stromal cells and osteoblasts. Comp. Biochem. \& Phys. Part B:

563 Biochem. \& Mol. Bio. 132:217-229.

564 Petes, L., Menge, B., \& A. Harris. 2008. Intertidal mussels exhibit energetic trade-offs between 565 reproduction and stress resistance. Ecol. Mono. 78:387-402.

566 Piano, A., Franzellitti, S., Tinti, F., \& E. Fabbri. 2005. Sequencing and expression pattern of

567 inducible heat shock gene products in the European flat oyster, Ostrea edulis. Gene 361:119-126.

568 Qu, Y., Li, X., Yu, Y., Vandepeer, M., Babidge, P., Clarke, S., Bott, K., \&H. Li. 2009. The effect

569 of different grading equipment on stress levels assessed by catecholamine measurements in

570 Pacific oysters, Crassostrea gigas (Thunberg). Aquacul. Engin. 40:11-16. 
$571 \quad R$ : A Language and Environment for Statistical Computing 2013. Vienna, Austria: R Foundation

572 for Statistical Computing.

573 Roberts, SB. 2017. RobertsLab/paper-Olurida-gene - Zenodo

574 http://doi.org/10.5281/zenodo.821216

575 Roberts, SB., Sunila, I., \& G. Wikfors. 2012. Immune response and mechanical stress

576 susceptibility in diseased oysters, Crassostrea virginica. J. of Comp. Phys. B 182:41-48.

577 Samain, J., Dégremont, L., Soletchnik, P., Haure, J., Bédier, E., Ropert, M., Moal, J., Huvet, A.,

578 Bacca, H., Van Wormhoudt, A., Delaporte, M., Costil, K., Pouvreau, S., Lambert, C., Boulo, V.,

579 Soudant, P., Nicolas, J., Le Roux, F., Renault, T., Gagnaire, B., Geret, F., Boutet, I., Burgeot, T.,

$580 \&$ P. Boudry. 2007. Genetically based resistance to summer mortality in the Pacific oyster

581 (Crassostrea gigas) and its relationship with physiological, immunological characteristics and

582 infection processes. Aquaculture 268:227-243.

583 Schmittgen, T. \& Livak, K. Analyzing real-time PCR data by the comparative CT method. 2008.

584 Nature Methods 3(6):1101-1108.

585 Sorger, P.K., \& Pelham, H.R. 1987. Cloning and expression of a gene encoding hsc 73, the major 586 hsp70-like protein in unstressed rat cells. The EMBO Journal 6:993-998.

587 Sokolova, I., Frederich, M., Bagwe, R., Lannig, G.,\& A. Sukhotin. 2012. Energy homeostasis as

588 an integrative tool for assessing limits of environmental stress tolerance in aquatic invertebrates.

589 Mar. Env. Res. 79:1-15.

590 Somji, S., Todd, J.H., Sens, M.A., Garrett, S.H., \& Sens, D.A. 1999. Expression of the

591 constitutive, inducible forms of heat shock protein 70 in human proximal tubule cells exposed to

592 heat, sodium arsenite, and $\mathrm{CdCl}(2)$. Environmental Health Perspectives 107:887-893.

593 Tomanek, L. 2010. Variation in the heat shock response and its implication for predicting the

594 effect of global climate change on species' biogeographical distribution ranges and metabolic

595 costs. J. of Exp. Bio. 213:971-979.

596 Truebano, M., Burns, G., Thorne, M., Hillyard, G., Peck, L., Skibinski, D., \& M. Clark. 2010.

597 Transcriptional response to heat stress in the Antarctic bivalve Laternula elliptica. J. of Exp. Mar.

598 Bio. and Eco. 391:65-72.

599 Wang, T., Yang, H., Zhao, H., Chen, M., \& Wang, B. 2011. Transcriptional changes in epigenetic 600 modifiers associated with gene silencing in the intestine of the sea cucumber, Apostichopus

601 japonicus (Selenka), during aestivation. Chinese J. of Ocean. and Limn. 29:1267-1274.

602 White, J., Ruesink, J., \& A. Trimble. 2009. The nearly forgotten oyster: Ostrea lurida Carpenter 6031864 (Olympia oyster) history and management in Washington State. J. of Shellfish Res. 28:4360449.

605 Wickham, H. 2014. plyr: Tools for splitting, applying and combining data.

606 Wickham, H.,\& W. Chang. 2014. ggplot2: An implementation of the Grammar of Graphics.

607 Wilson, E.B. 1927. Probable inference, the law of succession, and statistical inference. J. Am.

608 Stat. Assoc., 22, 209-212.

609 Xu, W., Chen, H., Du, K., Asahara, H., Tini, M., Emerson, B.M., Montminy, M., \& Evans, R.M.

610 2001. A transcriptional switch mediated by cofactor methylation. Science 294:2507-2511. 
611 Yao, C-L., \& G. Somero. 2012. The impact of acute temperature stress on hemocytes of invasive 612 and native mussels (Mytilus galloprovincialis and Mytilus californianus): DNA damage,

613 membrane integrity, apoptosis and signaling pathways. J. of Exp. Bio. 215:4267-4277.

\section{Figures}

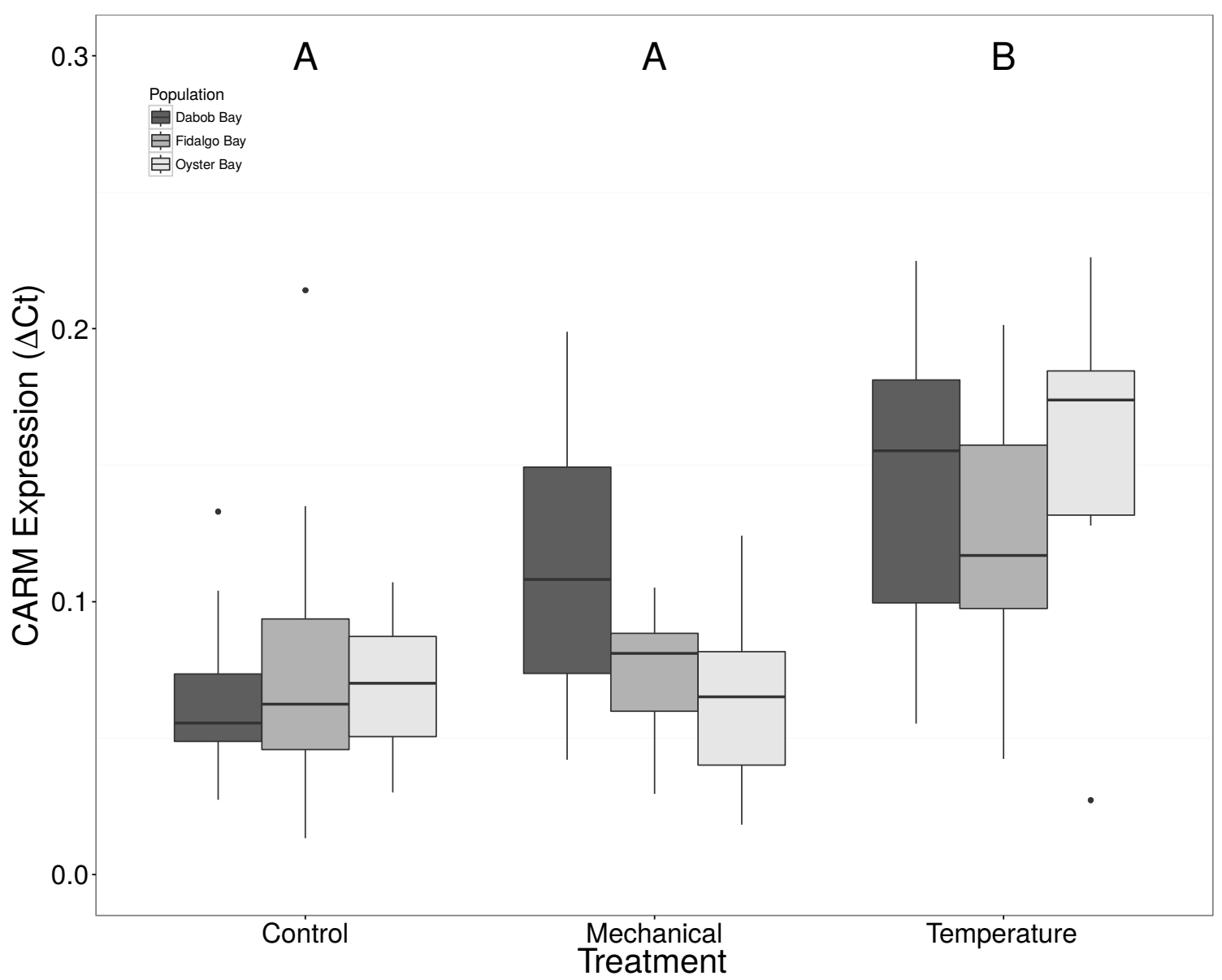

615 Figure 1. Expression of CARM1 mRNA. Median $\triangle \mathrm{Ct}$ indicated by line in middle of box plot. 616 Shaded boxes are 2nd and 3rd quartile groups. Lines are 1st and 3rd quartiles. Dots indicate 617 outside values. Capital letters indicate significant differences $(p<0.05)$ between overall treatment 618 groups $(n=24$ animals per treatment). No statistical differences $(p>0.05)$ were observed between 619 populations ( $\mathrm{n}=24$ animals per population), nor within a given population $(\mathrm{n}=8$ animals per 620 treatment). 


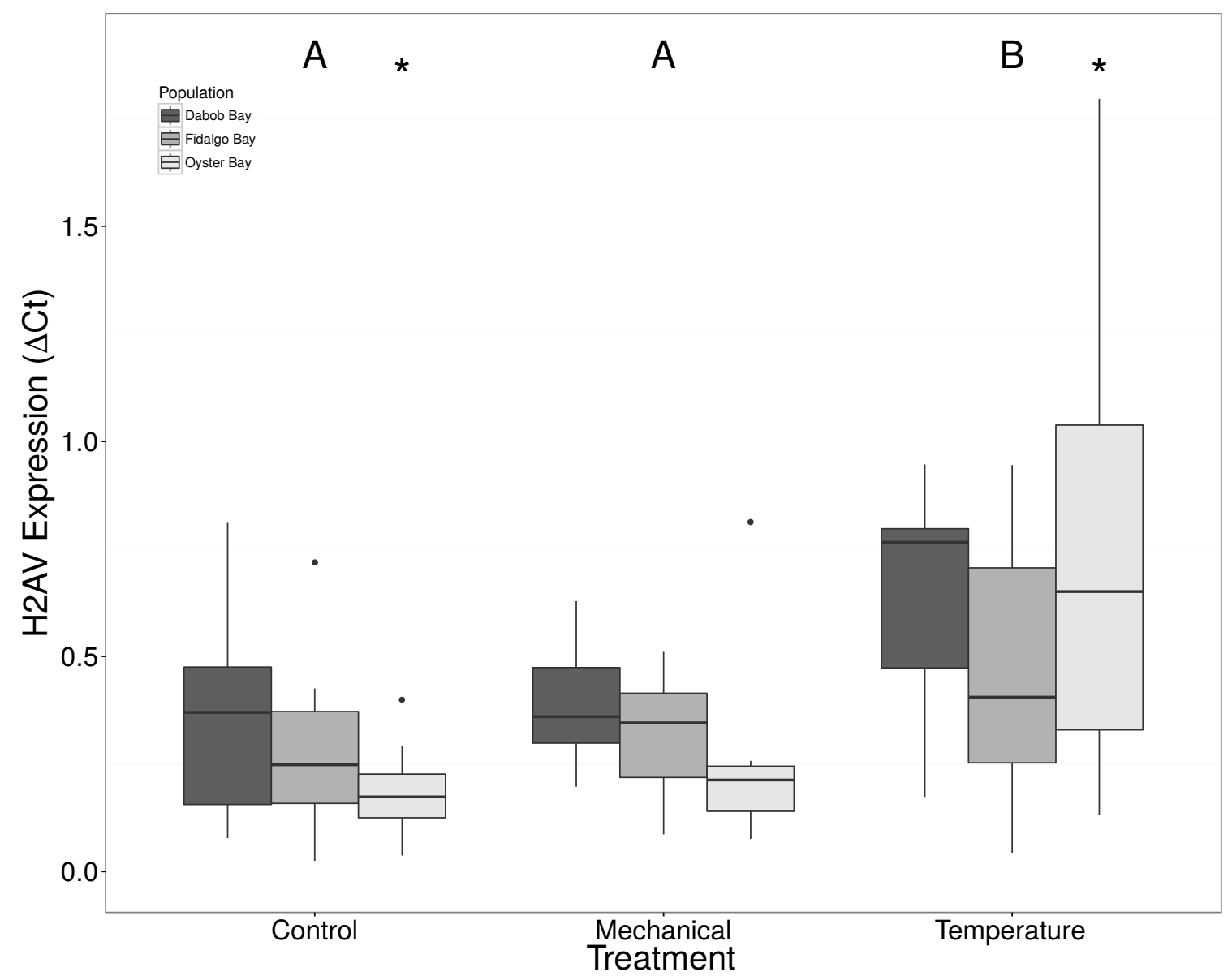

621 Figure 2. Expression of H2AV mRNA. Median $\Delta \mathrm{Ct}$ indicated by line in middle of box plot. 622 Shaded boxes are 2nd and 3rd quartile groups. Lines are 1st and 3rd quartiles. Dots indicate 623 outside values. Asterisks indicate significant differences $(\mathrm{p}<0.05)$ between treatments within a 624 population $(\mathrm{n}=8$ animals per treatment). Capital letters indicate significant differences $(\mathrm{p}<0.05)$ 625 between overall treatment groups $(n=24$ animals per treatment). No statistical differences $626(\mathrm{p}>0.05)$ were observed between populations ( $\mathrm{n}=24$ animals per population). 


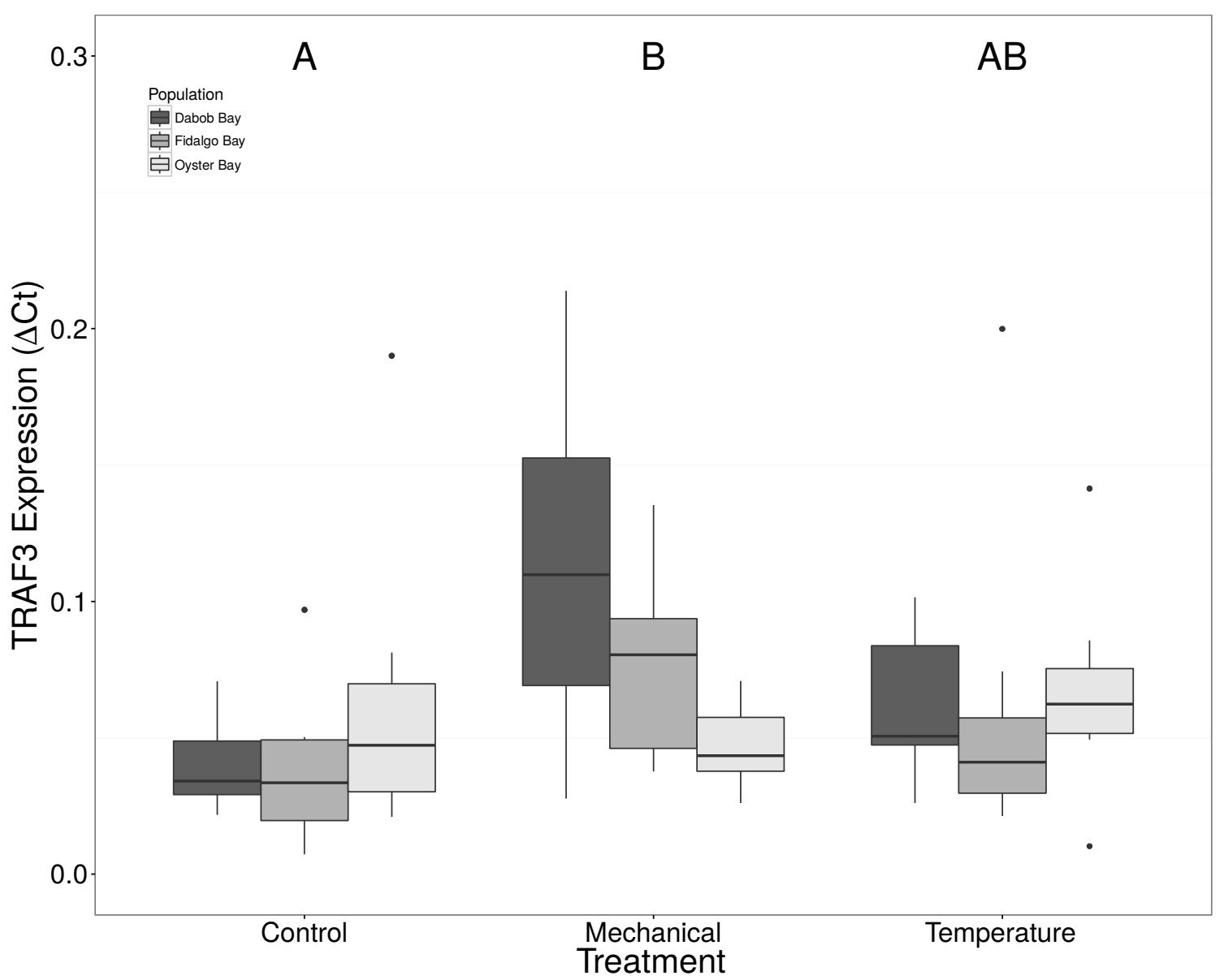

627 Figure 3. Expression of TRAF3 mRNA. Median $\triangle \mathrm{Ct}$ indicated by line in middle of box plot. 628 Shaded boxes are 2nd and 3rd quartile groups. Lines are 1st and 3rd quartiles. Dots indicate 629 outside values. Capital letters indicate significant differences $(p<0.05)$ between overall treatment 630 groups $(\mathrm{n}=24$ animals per treatment). No statistical differences $(\mathrm{p}>0.05)$ were observed between 631 populations ( $n=24$ animals per population), nor within a given population $(n=8$ animals per 632 treatment). 


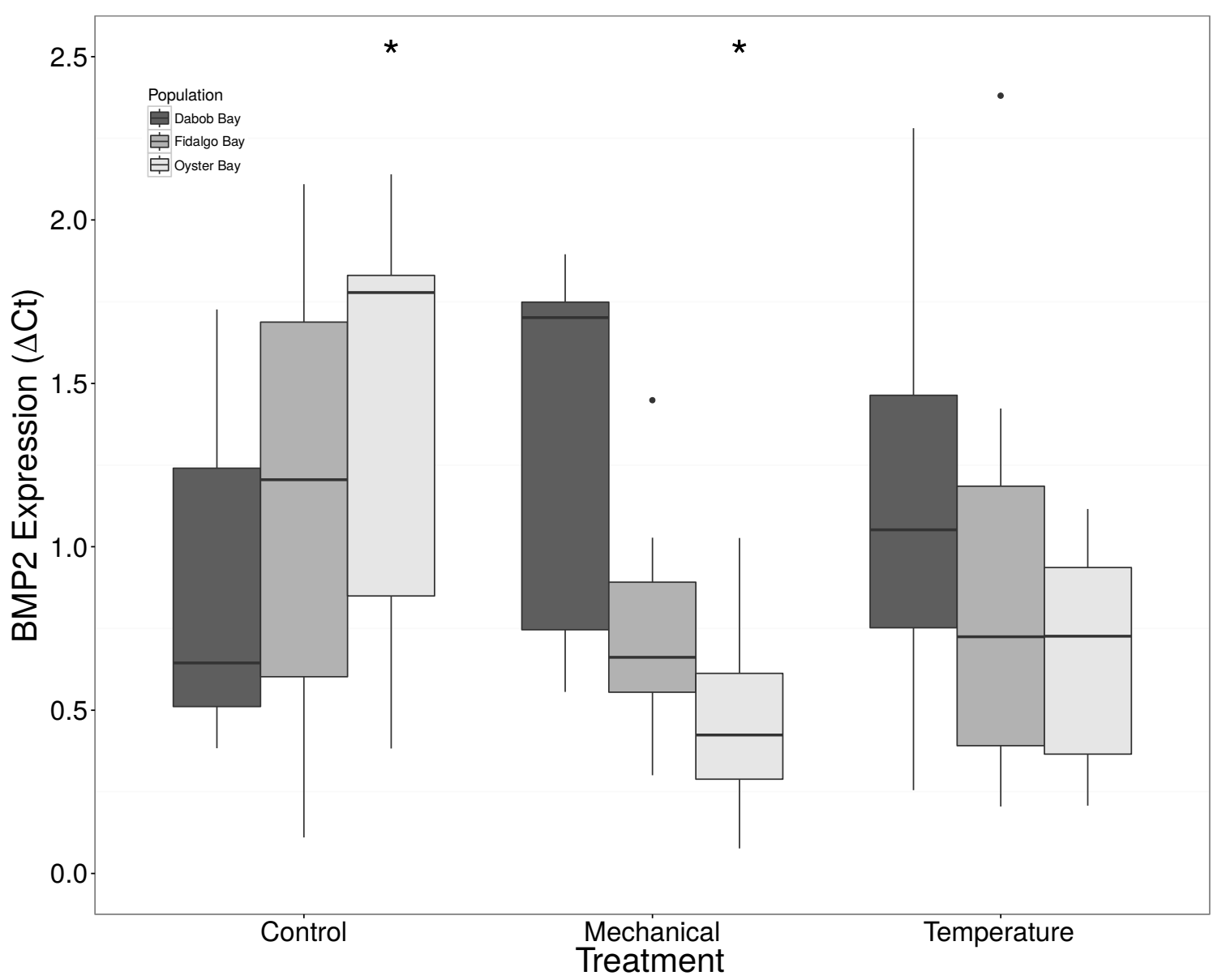

633 Figure 4. Expression of BMP2 mRNA. Median $\Delta \mathrm{Ct}$ indicated by line in middle of box plot. 634 Shaded boxes are 2nd and 3rd quartile groups. Lines are 1st and 3rd quartiles. Dots indicate 635 outside values. Asterisks indicate significant differences $(p<0.05)$ between treatments within a 636 population $(\mathrm{n}=8$ animals per treatment). No statistical differences $(\mathrm{p}>0.05)$ were observed 637 between populations ( $n=24$ animals per population), nor between treatments $(n=24$ animals per 638 treatment). 


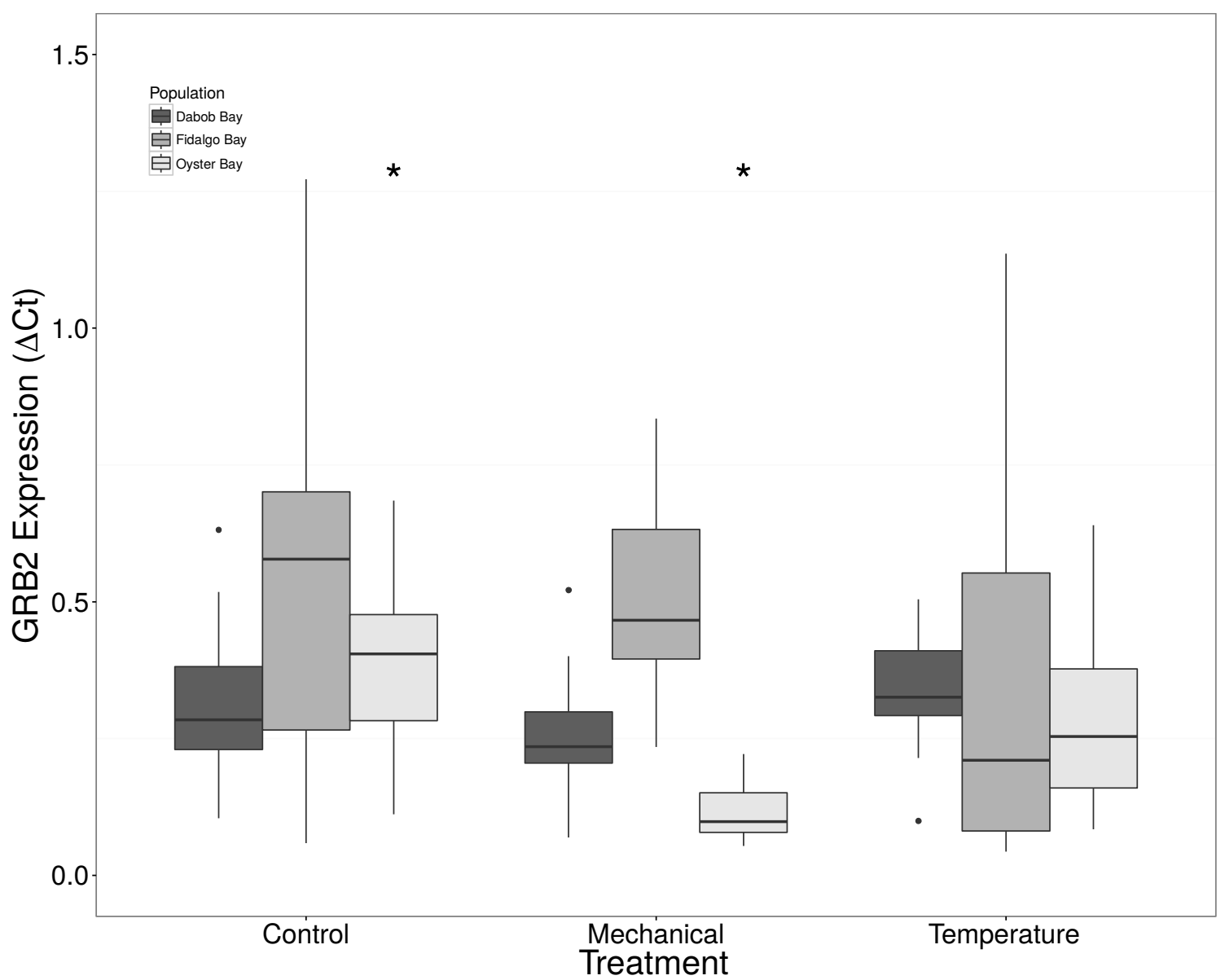

639 Figure 5. Expression of GRB2 mRNA. Median $\Delta \mathrm{Ct}$ indicated by line in middle of box plot.

640 Shaded boxes are 2nd and 3rd quartile groups. Lines are 1st and 3rd quartiles. Dots indicate 641 outside values. Asterisks indicate significant differences $(p<0.05)$ between treatments within a 642 population ( $\mathrm{n}=8$ animals per treatment). No statistical differences $(\mathrm{p}>0.05)$ were observed 643 between populations ( $n=24$ animals per population), nor between treatments $(n=24$ animals per 644 treatment). 


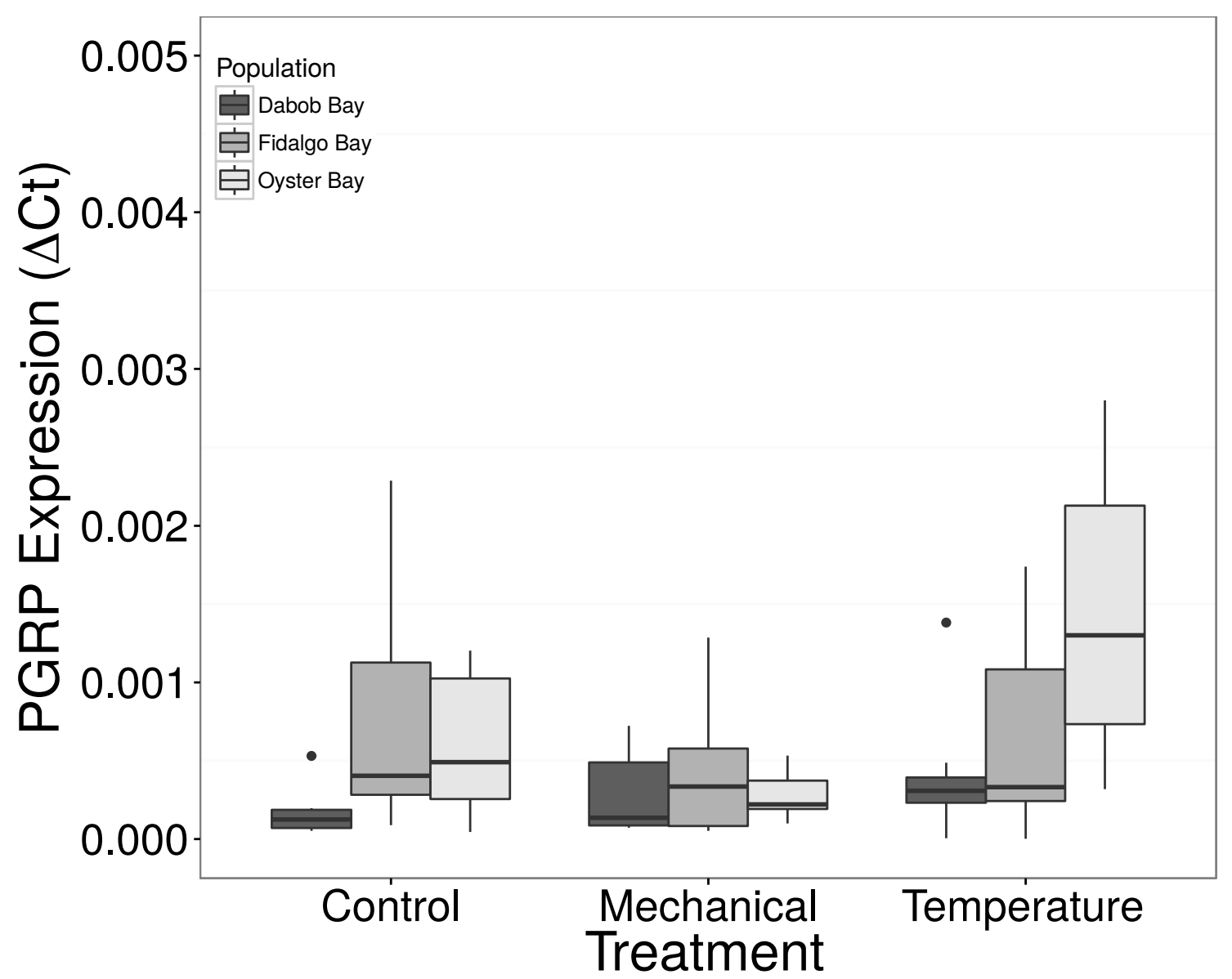

645 Figure 6. Expression of PGRP mRNA. No statistical difference observed between treatments, nor 646 between populations. Median $\Delta \mathrm{Ct}$ indicated by line in middle of box plot. Shaded boxes are $2 \mathrm{nd}$ 647 and 3rd quartile groups. Lines are 1st and 3rd quartiles. Dots indicate outside values. No 648 statistical differences $(\mathrm{p}>0.05)$ were observed within populations between treatments $(n=8$ 649 animals per treatment), between populations ( $\mathrm{n}=24$ animals per population), or between 650 treatments $(n=24$ animals per treatment $)$. 


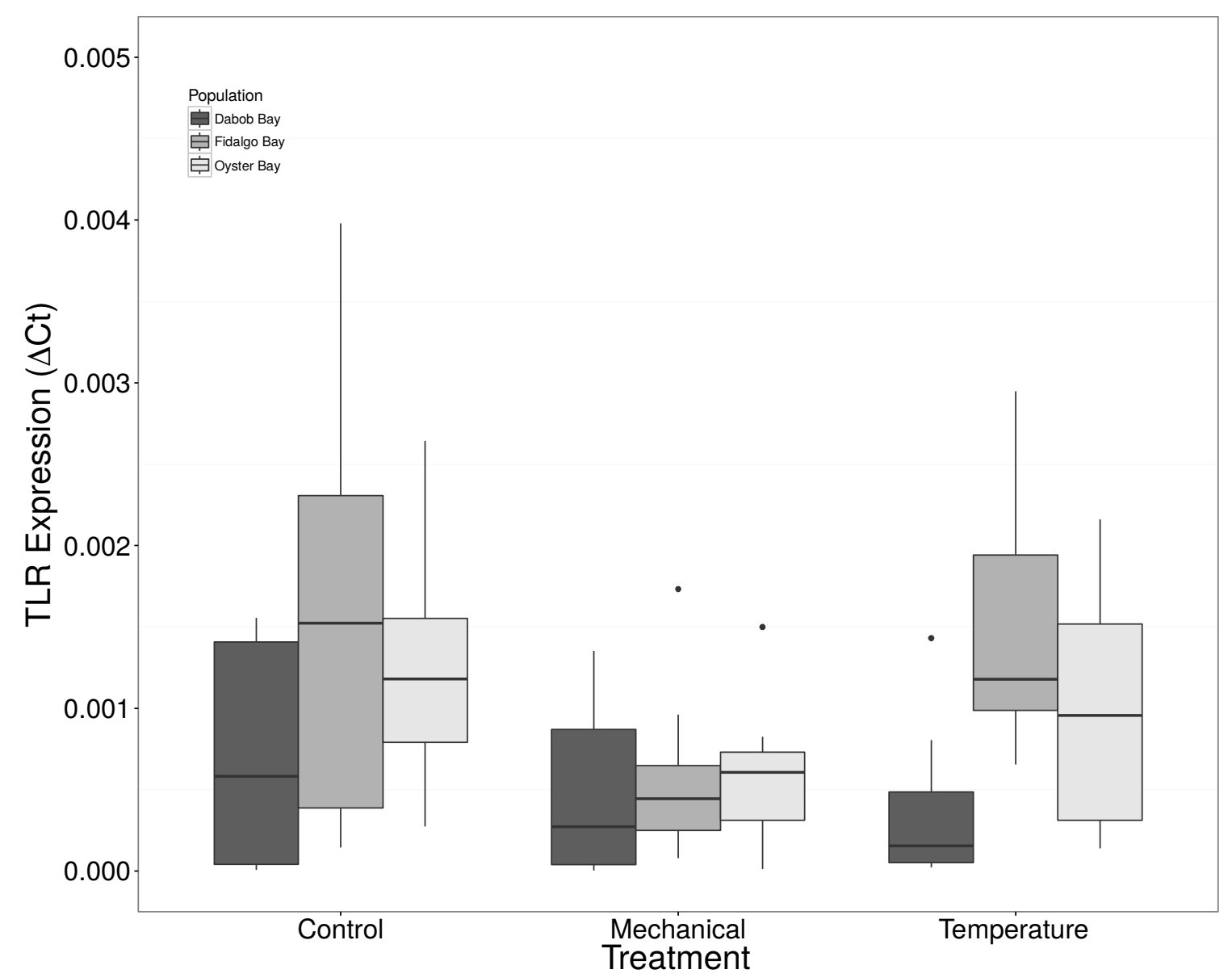

651 Figure 7. Expression of TLR mRNA. No statistical difference observed between treatments, nor 652 between populations. Median $\Delta \mathrm{Ct}$ indicated by line in middle of box plot. Shaded boxes are $2 \mathrm{nd}$ 653 and 3rd quartile groups. Lines are 1st and 3rd quartiles. Dots indicate outside values. No 654 statistical differences $(\mathrm{p}>0.05)$ were observed within populations between treatments $(n=8$ 655 animals per treatment), between populations ( $n=24$ animals per population), or between 656 treatments $(n=24$ animals per treatment $)$. 
0.15

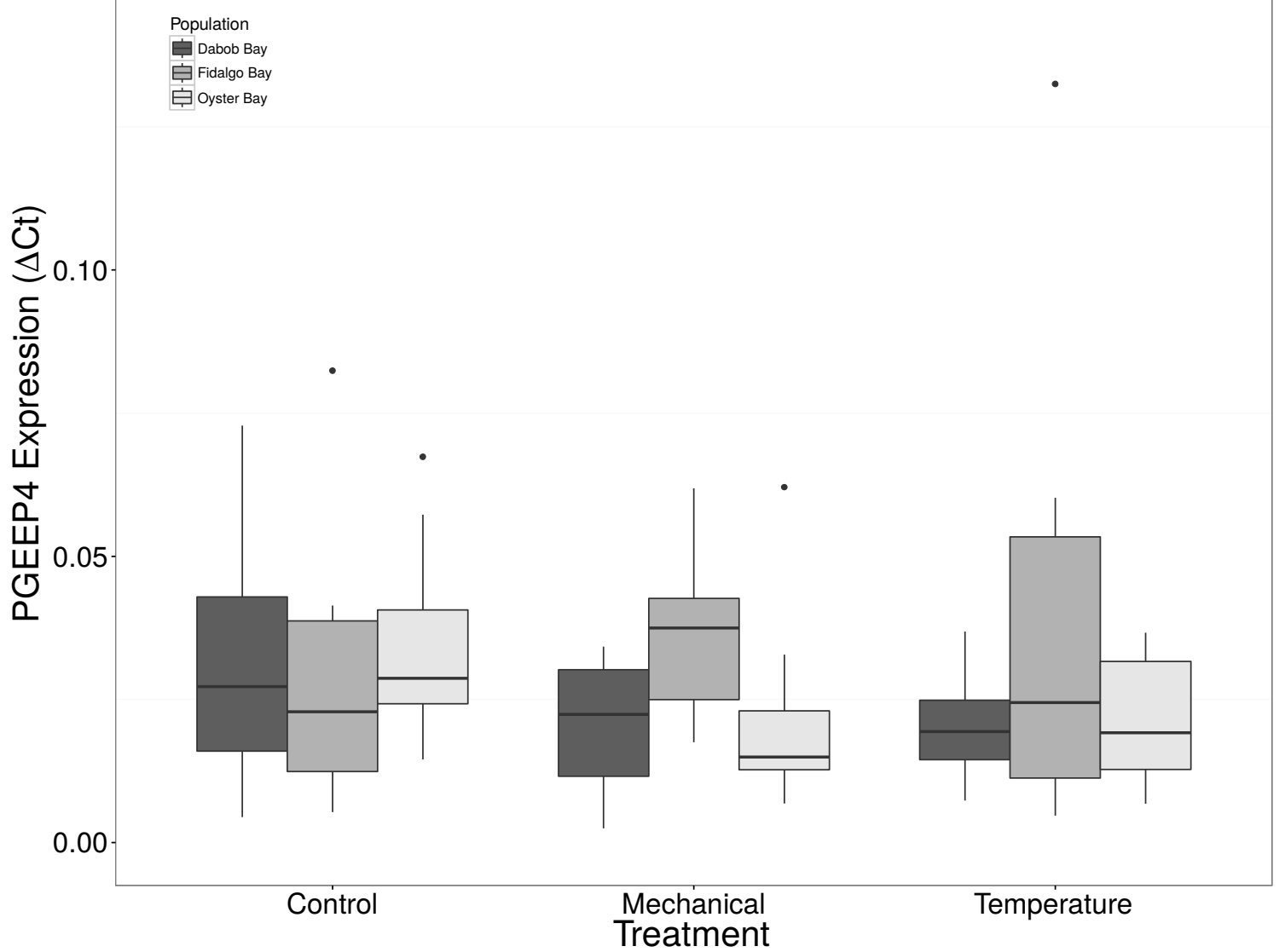

657 Figure 8. Expression of PGEEP4 mRNA. No statistical difference observed between treatments, 658 nor between populations. Median $\Delta \mathrm{Ct}$ indicated by line in middle of box plot. Shaded boxes are 659 2nd and 3rd quartile groups. Lines are 1st and 3rd quartiles. Dots indicate outside values. No 660 statistical differences $(\mathrm{p}>0.05)$ were observed within populations between treatments $(\mathrm{n}=8$ 661 animals per treatment), between populations ( $n=24$ animals per population), or between 662 treatments $(n=24$ animals per treatment $)$. 


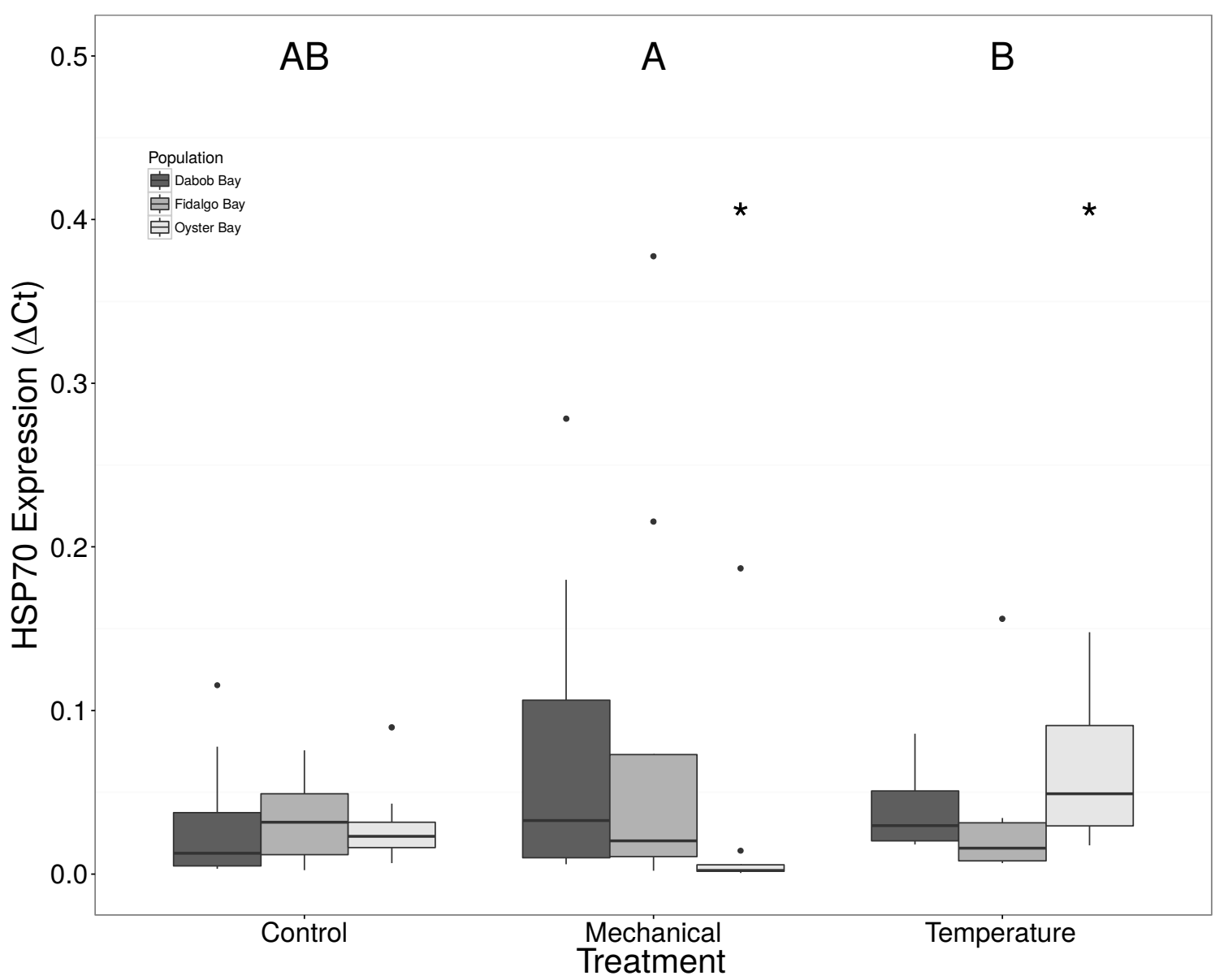

663 Figure 9. Expression of HSP70 mRNA. Median $\Delta \mathrm{Ct}$ indicated by line in middle of box plot.

664 Shaded boxes are 2nd and 3rd quartile groups. Lines are 1st and 3rd quartiles. Dots indicate 665 outside values. Asterisks indicate significant differences $(\mathrm{p}<0.05)$ between treatments within a 666 population ( $\mathrm{n}=8$ animals per population). Capital letters indicate significant differences $(\mathrm{p}<0.05)$ 667 between overall treatment groups $(n=24$ animals per treatment). No statistical differences $668(\mathrm{p}>0.05)$ were observed between populations ( $\mathrm{n}=24$ animals per population). 